\title{
JUURNAL.RU
}

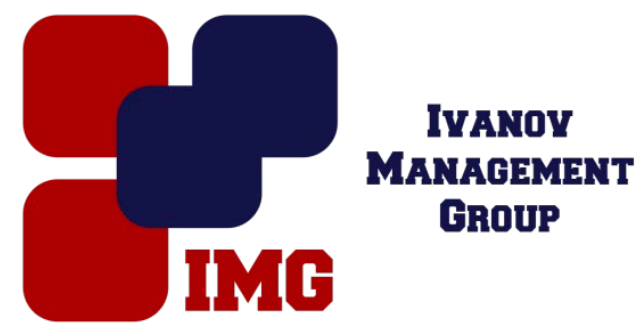

Назмутдинов Р.Т. Алтайский государственный университет Барнаул, Россия

doi: 10.18411/lj-31-10-2016-1-09

idsp 000001:lj-31-10-2016-1-09

\section{Концепция информационной системы экспертной оценки ВКР в ВУЗе на основе метода Дельфи}

Современное высшее учебное заведение нуждается в эффективной системе управления, успешное функционирование которой невозможно без мощной информационной поддержки. ВУЗ, с одной стороны, обладает всеми чертами крупной организации, оказывающей услуги, и, несомненно, информационная система ВУЗа может быть основана на ERP-технологии, с другой стороны, ВУЗ имеет свою специфику - осуществление образовательной и научной деятельности [1].

Важной отличительной особенностью высших учебных заведений является наличие слабо формализированных задач, решение которых возможно только с применением экспертных оценок или иных методов принятия управленческих решений. Одной из таких сложных задач является оценка ВКР студентов. Для независимой оценки ВКР студентов набирается комиссия, которая является экспертной группой. Наиболее проверенным методом, по мнению автора, по применению экспертных оценок является метод Дельфи.

Метод Дельфи - инструмент, позволяющий учесть независимое мнение всех участников группы экспертов по обсуждаемому вопросу путем последовательного объединения идей, выводов и предложений [2]. Целью метода является получение согласованной информации высокой степени достоверности в процессе анонимного обмена мнениями между участниками группы экспертов для принятия решения. Известно, что использование 
коллективных знаний ведет к возможности нахождения сильных решений, однако в процессе обмена мнениями между участниками может сказаться влияние авторитета коллег и все сведется к появлению популярных ответов. Метод Дельфи позволяет разрешить это диалектическое противоречие. Также необходимо ввести ранги «важности» эксперта, соответствующие его имиджу, известности в ученом мире или в практической области, опыту в изучаемой сфере, занимаемой должности, ученому званию или ученой степени и т.д. Для упрощения расчета можно приравнять сумму рангов к 100 относительно всего количества экспертов [4].

После того как группа экспертов ознакомилась с ВКР студента, им выдается задание в форме заранее подготовленной анкеты. Например, качество выполненной работы, презентации, ответы на вопросы и т.д. По ответам экспертов строится ряд распределения, и исчисляются основные его характеристики. Чем меньше вариативность, тем больше согласованность ответов и, следовательно, их надежность. Распределение ответов ранжируется по атрибутивным, или количественным, признакам [3]. Средняя величина или оценка за выполнение ВКР рассчитывается как отношение суммы всех оценок к общему числу экспертов, т.е. как простая средняя арифметическая:

Рассмотрим концепцию информационной системы поддержки принятия решения по оценке ВКР студентов в ВУЗе. Физически данная может быть реализована как веб-приложение. При реализации интерфейса для реализации необходимых технологий, можно использовать стандартные Javascriptфреймворки, например, Webix, и РНP-фреймворкҮii 2.0, которые позволят максимально быстро обмениваться данными по технологии "Клиент-Сервер". Бизнес-процесс работы системы достаточно простой и линейный, и в основном несет информационный характер.В первую очередь модератор системы формирует экспертную группу или комиссию, а также описывает критерии оценки ВКР. После этого эксперты получает уведомления о том, что начинается заочная оценка ВКР в системе, где они могут заранее ознакомиться с содержанием работ студентов. При необходимости эксперт может оставить комментарий или дополнительные вопросы к работе. Далее проходит очная презентация работы студентом перед комиссией, после которой производится обобщение результатов оценивания и оглашение результатов. 
Предлагаемая информационная система поддержки принятия решений экспертной группой ускоряет процесс принятия решения по оценке ВКР за счет возможности удаленной работы экспертов [1], а также делает процесс более справедливым, благодаря разрешению диалектического противоречия между коллегами-экспертами.

\section{Литература}

1. А.Ю. Юдинцев, Г.Н. Трошкина. Концепция информационной системы поддержки принятия решений в ВУЗе. Сборник статей VI Всероссийской научно-практической конференции «Современные технологии в Российской системе образования» -г.Пенза, май 2008. - 131 с.

2. А.С. Добрынин. Коллективные методы принятия управленческих решений. Кадровое дело - март 2005.- 89 - 196 с.

3. И.В. Вовк. Принятие управленческих решений. Вестник Оренбургского государственного университета, выпуск №2 -г.Оренбург, февраль 2013.104 c.

4. http://www. inventech.ru - портал «Центр креативных технологий».

5. А.Ю. Юдинцев, Г.Н. Трошкина. К вопросу о показателях и критериях управления качеством ВУЗа. Сборник статей VI Всероссийской научнопрактической конференции «Современные технологии в Российской системе образования〉 - г.Пенза, май 2008. - 128 с. 